DOI: $10.31933 /$ DIJEMSS

Received: $15^{\text {th }}$ July 2020, Revised: $15^{\text {th }}$ September 2020, Publish: $17^{\text {th }}$ November 2020

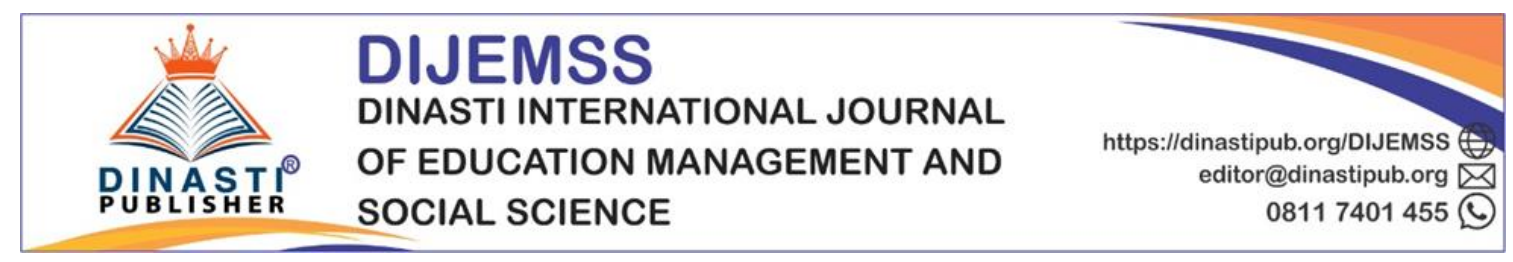

\title{
THE IMPACT OF JOB SATISFACTION AND EMPLOYEE ENGAGEMENT ON ORGANIZATIONAL COMMITMENT
}

\author{
Sutiyem $^{1}$, Dessy Trismiyanti ${ }^{2}$, Muthia Roza Linda ${ }^{3}$, Riza Yonita ${ }^{4}$, Suheri $^{5}$ \\ 1) STIE Perdagangan, Indonesia \\ 2) STIE Perdagangan, Indonesia \\ 3) Universitas Negeri Padang, Indonesia, muthia@fe.unp.ac.id \\ 4) Universitas Putra Indonesia "YPTK", Indonesia \\ 5) STIE Perdagangan, Indonesia
}

\section{Corresponding Author: Muthia Roza Linda}

\begin{abstract}
Abstrak: This study aimed to analyze the influence organization comitment, Job Satisfaction and Employee Engagement. The research was conducted by taking samples of banking employees who had worked for more than 2 years. Then, the sample of this study was 125 respondents. The sampling technique was carried out based on a nonprobability sampling method with a purposive sampling technique. It is a method that is based on certain criteria met by respondents with the data analysis technique used for hypotheses testing was multiple linear regression analysis through the program of SPSS ver. 24. The results showed that Job satisfaction does not significantly influence the organizational commitment of banking employees in Padang. The results of this study showed that sig. value of job satisfaction on organizational commitment was $0.592>$ 0.05 but Employee engagement has a positive and significant effect on the organizational commitment of banking employees in Padang. The results of this study revealed that sig. The value of employee engagement on organizational commitment was $0.000<0.05$.
\end{abstract}

Keywords: Organization Commitment, Job Satisfaction, and Employee Engagement.

\section{INTRODUCTION}

Banking is a company with high technology and high service. Excellent service has always been a demand for banking companies to be more competitive. This requires a high level of employee commitment so that a company can provide excellent service for its customers. Employee commitment is very necessary for a company even though this is crucial in the banking industry because employees in the banking industry are also faced with a lot of workloads, which sometimes require them to work on holidays. 
As part of high technology and high service company, banking is also supported by the development of information technology and science in its operational activities so that high commitment of its employees is required to carry out its business process. High employee commitment to a company is one of the guarantees for the company to maintain the sustainability of the company. According to Leitninger (2008) a company with highly commited employees will bring in very good benefits for the company. It is in line with Robbins and Judge (2013) who also state that committed employees will have little possibility for them to be involved in things that can harm the company because they have a high sense of loyalty. The reason of this is that work commitment of employees to a company is defined as the emotional bond between the employees and the company including their loyalty, job involvement and trust in company values (O'Reily in Sopiah, 2008).

There are some factors that influence employee commitment to an organization; therefore, knowing what factors bring about or foster employee commitment is necessary. Van Dyne and Graham (in Coetzee, 2005) mention some factors affecting one's organizational commitment according to multi-dimensional approach: positional factors, situational factors, and personal factors. Additionally, employee engagement is the main determinant of organizational commitment.

Employee engagement is a term which is popular and widely used. According to Robbins and Judge (2013) employee engagement is an individual's enthusiasm, satisfaction and involvement in the work he/she does. Moreover, employee engagement according to Harter et al. (2002) in Endres \& Mancheno-Smoak, (2008) is the involvement and satisfaction of an individual and also a sense of enthusiasm for work. Furthermore, Schaufeli \& Bakker, (2004) found that engagement was positively related to organizational commitment.

The other factor that affects organizational commitment is job satisfaction. Previous studies revealed that personal characteristics, job expectations and job satisfaction had positive influence on employee commitment to the organization (Susanti, 2013; Schwepker, 2014; Mulki et al, 2008; Fitria \& Linda, 2020). According to Mathis and Jackson (2006), job satisfaction is something interesting and crucial, basically regarding the impact of job satisfaction on work commitment of employees. Employees may be more productive if they have commitment towards the organization. People will be more committed to an organization when their work makes them relatively satisfied.

\section{LITERATURE REVIEW}

\section{Organizational Commitment}

"Organizational commitment is the degree to which employees believe in and accept organizational goals and desire to remain with the organization" (Mathis and Jackson, 2006). Organizational commitment is defined as a certain level in which an employee can identify the organization and the goals of the organization and then hope to be able to maintain membership in the organization (Robbins and Judge, 2013). Commitment causes a person's survival in an organization and has implications for the efforts made by the employee to compete in order to maintain their membership or to 
obtain a better position in organizational membership structure. This sense of engagement is not only shown through employees' daily attitudes but also in terms of psychological side or employees' way of thinking. An indication that an employee has organizational commitment is the emotional affection of the employee to the organization that has hired him/her (Karim and Rehman, 2012).

Organizational commitment is defined as the degree to which employees are involved in the organization and hope to remain members, with the attitudes of loyalty and willingness to work optimally for the organization where they work (Greenberg and Baron, 2003). According to Daft (2003) organizational commitment is an important attitude that influences performance. Daft defines organizational commitment as high loyalty and involvement in an organization. Employees with a high degree of organizational commitment will involve themselves in the organization and work on behalf of the organization.

Mathis and Jackson (2006) suggest that organizational commitment is the level to which an employee believes and accepts organizational goals and desires to stay with the organization. With the commitment of a local government, he/she will have an attitude of loyalty and desire to achieve the goals of his/her organization well. Meanwhile, according to Luthans (2006), organizational commitment is defined as a strong desire to remain as a member of a particular organization, a desire to strive according to the expectations of the organization, and certain belief and acceptance of organizational values and goals.

Based on the above-mentioned definitions, it can be concluded that organizational commitment is a condition in which an individual has encouragement or desire to remain in an organization and believes in the values of the organization.

\section{Indicators of Organizational Commitment}

Robbins and Judge (2013) classify three separate indicators of organizational commitment, as follows:

1. Affective commitment. Someone who has a strong affective commitment will continue to work in an organization because he/she really wants to do that.

2. Continuance commitment. An employee may survive and commit to an organization and the employer(s) because he/she is given quite much salary. This commitment causes an employee to stay in an organization because he/she needs it.

3. Normative commitment. This commitment causes an employee to stay on a job because he/she feels obliged to do it.

\section{Job Satisfaction}

Job satisfaction refers to a pleasant or unpleasant emotional state of an employee with his/her work (Danang, 2015). Then, job satisfaction reflects a person's feeling in his/her job. This can be seen from the positive attitude of an employee towards his/her work and everything that is encountered in his/her work environment. Robbins and Judge (2013) specifically describe job satisfaction as a person's positive feeling for his/her work obtained from the evaluation on characteristics of the satisfaction itself. This positive 
feeling is generally identical to the sense of happiness and comfort because someone's expectations from his/her work have been fulfilled.

Job satisfaction is a factor that also determines the effectiveness and productivity of work. According to Handoko (2001) job satisfaction is a pleasant or unpleasant emotional state with which an employee views his/her work. It is in line with the idea of Dole and Schroedr, 2001 (in Koesmono, 2005) that job satisfaction can be defined as the feeling and reactions of an individual to his/her work environment. Based on this definition, it can be concluded that job satisfaction is the feeling of being happy or unhappy about an employee's work as a result of a comprehensive evaluation of aspects of work.

According to Luthans (2006) there are three dimensions of job satisfaction that are generally accepted. Firstly, job satisfaction is an emotional response to work situations. Secondly, job satisfaction is often determined according to how well the results achieved meet or exceed the expectations. If members of an organization feel that they work too hard than others do in a department, but receive less appreciation, then maybe they have a negative attitude towards their work, leaders, or colleagues. They are not satisfied. Conversely, if they feel treated well and paid properly, then they will have a positive attitude towards their work. They feel satisfied. Third, job satisfaction represents several related attitudes in which an employee has affective responses, including: the job itself, salary, promotion opportunities, supervision, colleagues. According to Luthans (2006) high job satisfaction will not make employee turnover become low, but conversely if there is job dissatisfaction, then employee turnover may be high.

There are various dimensions of which job satisfaction can be measured. However, the dimensions, in general, include satisfaction from the job itself, recognition, salary, opportunities to progress, and relationship between employees and supervisors. Each dimension creates a feeling of satisfaction as a whole with the work itself. Additionally, Robbins \& Judge (2013) mention 5 factors supporting job satisfaction, as follows:

1. Challenging Job

Employees tend to prefer the work which provides opportunities to use their abilities and skills, and offers various tasks, freedom, and feedback regarding how they do them.

2. Compensation

Perception of fairness is one of the most crucial things in examining the relationship between job satisfaction and compensation. The determination of fairness can be according to the size of work responsibilities and demands, the standard of salary, the level of individual employees' skills, and the severity of work.

3. Supporting working conditions

Work environment is concerned by employees for two reasons: personal comfort and facilitating their tasks. They would rather have work environment which is not troublesome or dangerous.

4. Supporting colleagues 
Most employees perceive that, by working, their need for social interaction is also fulfilled. Consequently, it is clear that job satisfaction can be increased by having friendly and supportive colleagues.

5. Compatibility of personality with work

The compatibility of personality of employees with their types of work will lead to higher satisfaction. This will result in bigger opportunities to be successful in their work.

\section{Employee Engagement}

Robbins and Judge (2013) define employee engagement as enthusiasm, satisfaction and involvement of an employee in the work he/she does. In addition, engagement actively involves emotions and behavior, and entails cognitive aspects. May et al., (2004; in Saks, 2006). Then, Robinson, Perryman, Hayday (2004); Kular, Gatenby, Ress, Soane, Truss (2008) in Johan, (2014) state that employee engagement is an employee's positive attitude to an organization and its values.

Schaufeli and Bakker, Rothbard (in Saks, 2006) define engagement as a psychological involvement which further involves two important components, namely attention and absorption. Attention refers to the cognitive availability and the total time spent by an employee in thinking and performing his/her role, while absorption means defining the role and refers to the intensity of an employee focusing on his/her role in the organization. So, it can be concluded that employee engagement is a level of an employee's engagement and involvement emotionally, physically, and cognitively in an organization.

Engagement is carried out on how individuals empower themselves to achieve performance in their work. As stated by Macey and Schneider (2008), in Johan (2014), employees who are engaged to an organization have the awareness of business context and work with their colleagues in order to enhance work performance for the sake of the organization. Similarly, Evan, 2010 in Agung (2012) says that employee engagement is very crucial to encourage an organization accomplish its best performance.

Employee engagement can be seen as the power that provides motivation for an employee to improve performance at a higher level than before. The power can be in the forms of commitment for both company and his/her job, sense of belonging to the job, feeling of pride, more effort than usual, and enthusiasm for completing the work (Wellins \& Concelman in Endres \& Smoak, 2008).

Moreover, Schaufeli \& Bakker, (2004) also state that engagement is positively related to job satisfaction and organizational commitment; it is negatively associated with intention to leave; and it is also believed to be related to performance and OCB. In addition, Saks's (2006) study could prove that job satisfaction, intention to leave, organizational commitment, and Organizational Citizenship Behavior (OCBO and OCBI) were consequences of employee engagement.

Employee engagement basically cannot be separated from employee job satisfaction, which in turn can create positive employee morale for the sake of organization. As stated by Schmidt, Law, Hunter, Roethsen, Pearlman, McDaniel (1993) 
in Johan (2014), employee engagement is basically based on the employee's commitment and job satisfaction; in other words, employee engagement is a modern version of the concept of job satisfaction.

Characteristics of employee engagement mean characteristics considered to be able to affect an individual's engagement in a company. Schaufeli et al (2002) then mention three characteristics of employee engagement, namely:

a. Vigor. The characteristics are mental toughness at work, high level of energy, endurance in dealing with adversity, and desire to put effort into work.

b. Dedication. The characteristics are inspiration, enthusiasm, challenges and pride.

c. Absorption. The characteristics are pleasure and full concentration when involved in work, therefore it seems that time runs fast even if faced with troubles.

\section{Conceptual Framework}

An organization needs to be aware of things that cause or improve commitment in order to increase commitment to the organization. Previous studies have come to a conclusion that job satisfaction and employee engagement affect employee commitment to an organization. The conceptual framework of this study is as follows:

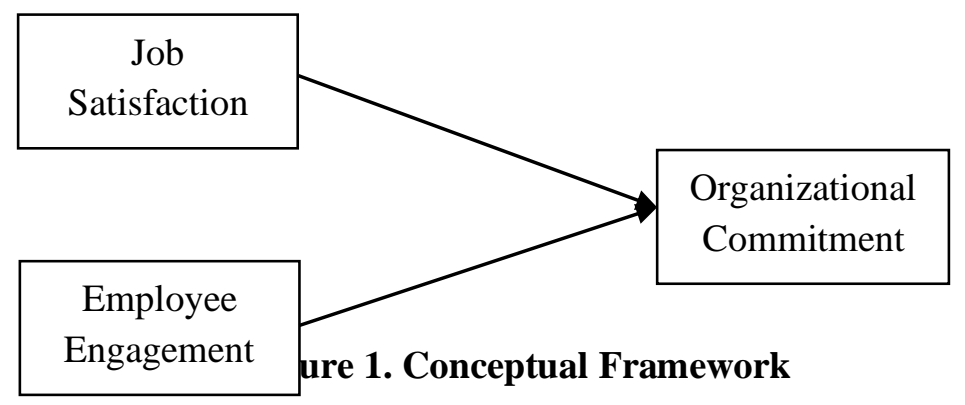

\section{Hypotheses}

The hypotheses of this study were:

H1. Job satisfaction has a positive and significant effect on employee organizational commitment

H2. Employee engagement has a positive and significant effect on employee organizational commitment.

\section{RESEARCH METHOD}

In conducting a study, sampling is needed to simplify the process of study because it is not possible for all existing population to be examined due to the limited ability of a researcher. According to Arikunto (2010), sample is part or representatives of the population under study. The number of respondents for a survey study is minimal 30 respondents (Hair, et al. 2014). This study was a survey study of which an advantage is its generalization, the more respondents take part the better the study is (Kerlinger \& Lee, 2000). So, the researchers attempted to have respondents more than the minimum requirement in order that the precision in this study would be better.

The sampling technique was carried out based on non-probability sampling method with purposive sampling technique. It is a method which is based on certain criteria met 
by respondents. The criterion that had to be met by the respondents were that the respondents were banking employees who had worked for more than 2 years. Then, the sample of this study was 125 respondents.

The data used in this study were primary data obtained in a raw and direct form from the research respondents. The primary research data were obtained through questionnaires distributed directly to be filled by the respondents. The data analysis technique used for hypotheses testing was multiple linear regression analysis through the program of SPSS ver. 24

\section{Operational Definitions}

In this study there were two types of variables, namely independent variable and dependent variable. The independent variables were job satisfaction and employee engagement, while the dependent variable was organizational commitment. In order to have same understanding of the variables used in this study, the authors provide operational definitions in Table 1 below:

Table 1. Operational Definitions

\begin{tabular}{|l|l|l|l|}
\hline No & \multicolumn{1}{|c|}{ Variable } & \multicolumn{1}{|c|}{ Indicator } & \multicolumn{1}{c|}{ Source } \\
\hline 1. & $\begin{array}{l}\text { Organizational } \\
\text { Commitment }\end{array}$ & $\begin{array}{l}\text { a. Affective commitment. } \\
\text { b. Continuance commitment. } \\
\text { c. Normative commitment. }\end{array}$ & $\begin{array}{l}\text { Mowday } \text { et al, 1982 } \\
\text { (dalam Sopiah, 2008) }\end{array}$ \\
\hline 2. & Job Satisfaction & $\begin{array}{l}\text { a. Challenging Job } \\
\text { b. Compensation } \\
\text { c. Supporting working } \\
\text { conditions } \\
\text { d. Supporting colleagues } \\
\text { e. Compatibility of } \\
\text { personality with work }\end{array}$ & $\begin{array}{l}\text { Robbins and Judge } \\
(2013)\end{array}$ \\
\hline 3. & $\begin{array}{l}\text { Employee } \\
\text { Engagement }\end{array}$ & $\begin{array}{l}\text { a. Vigor } \\
\text { b. Dedication } \\
\text { c. Absorption }\end{array}$ & Schaufeli et al (2002) \\
\hline
\end{tabular}

\section{RESEARCH FINDINGS}

Before testing the hypotheses, the research instruments were first tested in terms of validity and reliability. The result of validity test showed that the overall data had the value of corrected item-total correlation $>0.361$ with Cronbach's alpha value $>0.70$. After that, the data normality test was carried out to find out whether the data were normally distributed or not. The data normality test was done by using a graphical approach in the form of normal probability plot, that was by comparing cumulative distribution of the actual data with cumulative distribution of the normal distribution. Data is said to be normal if the data spreads around a diagonal line. The following is the figure of normal P-P plot. 


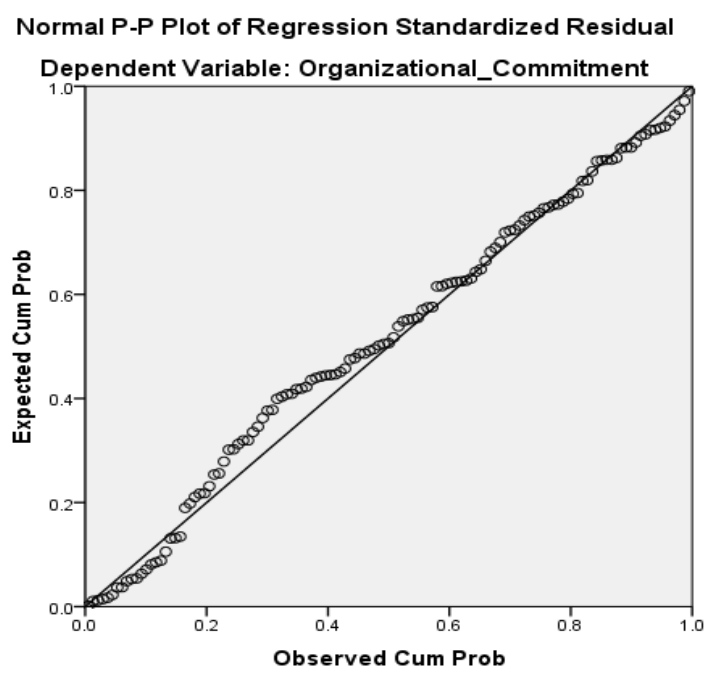

Figure 2. P-P Plot

Based on the figure above, it can be seen that the research data were spread along the diagonal line, so it can be concluded that the variables used in this study were normally distributed so that hypotheses testing could be carried out.

The regression coefficient of each independent variable and the direction of its influence on the dependent variable could be seen from the analysis of multiple regression data obtained by using the program of SPSS Version 24 as shown in the following table:

Table 2. The Results of Multiple Linear Regression of Research Variables Coefficients $^{\mathrm{a}}$

\begin{tabular}{|c|c|c|c|c|c|c|}
\hline \multirow{2}{*}{\multicolumn{2}{|c|}{ Model }} & \multicolumn{2}{|c|}{$\begin{array}{l}\text { Unstandardized } \\
\text { Coefficients }\end{array}$} & \multirow{2}{*}{$\begin{array}{c}\text { Standardized } \\
\text { Coefficients } \\
\text { Beta }\end{array}$} & \multirow[t]{2}{*}{$\mathrm{t}$} & \multirow[t]{2}{*}{ Sig. } \\
\hline & & $\mathrm{B}$ & Std. Error & & & \\
\hline \multirow[t]{3}{*}{1} & (Constant) & 1.549 & .456 & & 3.397 & .001 \\
\hline & Job_Satisfaction & .050 & .092 & .040 & .537 & .592 \\
\hline & Employee_Engagement & .597 & .081 & .555 & 7.368 & .000 \\
\hline
\end{tabular}

a. Dependent Variable: Organizational_Commitment

Source : The Results of Primary Data Processing (2020)

Based on the regression results seen from Table 2 above, the multiple linear regression equation in this study could be determined as follows:

$\mathrm{Y}=1.549+0.050 \mathrm{X} 1+0.597 \mathrm{X} 2+0.456$

$\mathrm{Y}$ : Organizational Commitment

$\mathrm{X}_{1}$ : Job Satisfaction

$\mathrm{X}_{2}$ : Employee Engagement

The interpretations of the regression equation obtained are as follows:

1) The constant was signed positive by 1.549 , meaning that the employees still had a positive organizational commitment to their work even though in doing their work the employees did not feel job satisfaction and employee engagement.

2) The regression coefficient of job satisfaction (X1) was 0.050 and positive. This indicated that the higher the job satisfaction was felt by the employees in working, the more increasing the employee organizational commitment would be. 
3) The regression coefficient of employee engagement (X2) was 0.597 and positive. This indicated that the higher the employee engagement is owned by the employees, the more increasing the employee organizational commitment would be.

4) The error value was 0.456 , meaning that the equation obtained still had a shortcoming in terms of predicting to what extent job satisfaction and employee engagement influence employee organizational commitment.

\section{DISCUSSION}

\section{Job Satisfaction on Organizational Commitment}

Based on the results of regression analysis undertaken, job satisfaction did not have a significant effect on organizational commitment with sig. $0.592>0.05$, meaning that organizational commitment of the banking employees was not influenced by job satisfaction felt by the employees. This was because, for the banking employees, they had already had organizational commitment since they joined the company. So, it was not due to the presence or absence of job satisfaction that the employees felt when working. For the employees themselves, the job as a banking employee had given them more value in the form of high prestige among society.

In addition, for some employees, as long as they had a job and the job was to support their lives, so they had a commitment to their job and the organization they worked for. From several interviews with the employees, job satisfaction did not affect their organizational commitment, because the employees considered their current job only a stepping stone, then later they would change their job if they got a job as their wish, such as being a civil servant. Even, some of the former employees had resigned from the job to become a teacher.

This result of study is not in line with the result of study conducted by Dewa and I Made Artha (2016) at Bali Rani Hotel that job satisfaction had a positive and significant influence on organizational commitment. Additionally, Ni Made Dwi and I Gede Riana (2014) in their study revealed that job satisfaction had a positive and significant impact on organizational commitment. Nevertheless, the result of study conducted by (Eka, 2014) supports the result of this study that job satisfaction did not significantly influence employee organizational commitment.

\section{Employee Engagement on Organizational Commitment}

In working, employees who are engaged to their work have full energy and high mental endurance, then it can influence employee commitment since the employees perceive that they are responsible for their work. So, employees who have employee engagement to their work will remain in the company because for them it is an obligation to carry out their tasks. It is supported by (Agyemang \& Ofei, 2013) who say that employee engagement has a positive and significant effect on organizational commitment.

The results of this study supported the hypothesis that employee engagement has a positive and significant effect on organizational commitment with sig. $0,000<0.05$, meaning that the higher the employee engagement is felt by employees, the higher the 
employee organizational commitment is. This result of study informs that companies need to create employee engagement so that the companies' goals can be achieved through the high organizational commitment of the employees.

This result of study is in line with the result of studies conducted by Schaufeli \& Bakker (2004) and Albdour \& Altarawneh (2014) that employee engagement was positively related to organizational commitment. This means that if employees are strongly engaged to an organization it can increase job satisfaction and employee commitment to the organization.

To find out how much influence the independent variable consisting of job satisfaction and employee engagement on organizational commitment (Y) on employees can be seen from the value of $\mathrm{R}$ square in the table below.

Tabel 3. Model Summary

\begin{tabular}{|l|c|c|c|c|}
\hline Model & $\mathrm{R}$ & $\begin{array}{c}\mathrm{R} \\
\text { Square }\end{array}$ & $\begin{array}{c}\text { Adjusted R } \\
\text { Square }\end{array}$ & $\begin{array}{c}\text { Std. Error of } \\
\text { the Estimate }\end{array}$ \\
\hline 1 & $.559^{\mathrm{a}}$ & .313 & .302 & .58809 \\
\hline
\end{tabular}
a. Predictors: (Constant), Employee_Engagement, Job_Satisfaction
b. Dependent Variable: Organizational_Commitment
Source : The Results of Primary Data Processing (2020)

From table 3 above, the R square value of 0.483 indicates that the contribution of the independent variable consisting of job satisfaction and employee engagement to the dependent variable, namely organizational commitment in this study was $31.3 \%$ while $68.7 \%$ was determined by other factors not examined in this study.

\section{CONCLUSIONS}

With regard to the research findings and the discussion elucidated in the previous subheadings, there are some conclusions that can be drawn in this study:

1. Job satisfaction does not significantly influence organizational commitment of banking employees in Padang. The results of this study showed that sig. value of job satisfaction on organizational commitment was $0.592>0.05$.

2. Employee engagement has a positive and significant effect on organizational commitment of banking employees in Padang. The results of this study revealed that sig. value of employee engagement on organizational commitment was $0.000<0.05$.

\section{REFERENCES}

Agung Nugroho Adi. 2012. Driving Performance and Retention To Employee Engagement: A Case Study In University Of Brawijaya. Journal of Basic and Applied Scientific Research ISSN 2090-4304. 338-350.

Agyemang, C. B., \& Ofei, S. B. 2013. Employee Work Engagement and Organizational Commitment a Comparative Study of Private and Public Sector Organizations in Ghana. European Journal of Business and Innovation Research, (14), 20-33

Albdour, A. A. \&Altarawneh, I. I. (2014). Employee Engagement and Organizational Commitment: Evidence from Jordan. International Journal of Business, 19 (2), hal: 193-212. 
Arikunto, S. 2010. Prosedur penelitian : Suatu Pendekatan Praktik (Edisi Revisi). Jakarta : Rineka Cipta

Coetzee, M. 2005. Employee Commitment. University of Pretoria etd. Accessed on may 20,2020

http://upetd.up.ac.za/thesis/Available/etd-

04132005130646/unrestricted/05chapter5.pdf.

Daft, Richard L.2003. Manajemen. Edisi Kelima. Jakarta: Erlangga

Danang Sunyoto. (2015). Manajemen dan Pengembangan Sumber Daya Manusia. Yogyakarta: Center for Academic Publishing Service.

Dewa Putu Prasetya Cahya Utama dan I Made Artha Wibawa. 2016. Pengaruh Kepuasan Kerja Terhadap Komitmen Organisasi Dan Organizational Citizenship Behavior Pada Karyawan Bali Rani Hotel. E-Jurnal Manajemen Unud, Vol. 5, No. 4, ISSN : 2302-8912. 2511-2453.

Dole, Carol and Schroeder, Richard G. 2001. The Impact of Varios Factors on the Personality, Job Satisfaction and Turn Over Intentions of Profesional Accountants. Managerial Auditing Journal, Vol. 16 No. 4

Eka Mariyanti. 2014. Pengaruh Keterlibatan Kerja Dan Kepuasan Kerja Terhadap Komitmen Organisasi. Jurnal KomTekInfo Fakultas Ilmu Komputer, Volume 1, No. 1. pp. 38-45

Endres, G.M. \& Mancheno- Smoak, L. 2008. The Human Resource Craze: Human. Organization Development Journal. Vol.26, No. 1.

Evans, D, McKee, J \& Bratton, S 2010, Social Media Marketing: The Next Generation of Business Engagement, Wiley Publishing, Canada.

Fitria. Y \& Linda. M. R,. (2020). Kepuasan Kerja: Sebagai Variabel Mediasi Hubungan Antara Employee Engagement dan Organizational Commitment. Jurnal Inspirasi Bisnis dan Manajemen, 4(1), 17-30.

https://www.researchgate.net/publication/342762371 Kepuasan Kerja Sebagai Variabel_Mediasi_Hubungan_Antara_Employee_Engagement_dan_Organizatio nal Commitment [accessed Jul, 15 2020].

Greenberg, J. and Baron, R.A. 2003. Behavior in Organizations Understanding and Managing The Human Side of Work. New Jersey: Prentice-Hall International

Hair, et al,. 2014. Multivariate Data Analysis, New International Edition., New Jersey : Pearson.

Handoko, T. Hani. 2001. Manajemen Personalia dan Sumber Daya Manusia. Yogyakarta: BPFE Yogyakarta

Harter, J. K., Schmidt, F. L., \& Hayes, T. L. (2002). Business-Unit Level Relationship Between Employee Satisfaction, Employee Engagement, and Business Outcomes: A Meta-Analysis. Journal of Applied Psychology Vol.87:hal.268-79

Johan Widjaja dan Devie. 2014. Pengaruh Job Satisfaction Terhadap Financial Performance Melalui Employee Engagement dan Competitive Advantage Sebagai Intervening Variable Pada Perusahaan Retail Publik di Surabaya. Business Accounting Review, Vol. 2, NO. 2, 201, 99-110.

Karim, F dan Omar Rehman, 2012.Impact of Job Satisfaction, Perceived Organizational Justice and Employee Empowerment on Organizational Commitment in SemiGovernment Organizations of Pakistan. Journal of Business Studies Quarterly 2012. 3 (4).

Kerlinger, F. N., \& Lee, H. B. 2000. Foundations of Behavioral Research $2^{\text {nd }}$. Harcourt College Publisher

Koesmono. (2005), Penilaian kinerja dan pengembangan karyawan. BPFE: Yogyakarta 
Kular, Sandeep., Gatenby, Mark., Ress, Chris., Soane, Emma., \& Truss. (2008). Employee Engagement: A Literature Review. Working Paper Series, No.19. Kingston University.

Leitninger, J. 2008. The Key to Retention: Commited Employees. Accessed on may 20, 2020.

http://www.mekonginsight.com//?p=556.

Luthans, Fred. (2006), Perilaku Organisasi. Edisi Sepuluh, PT. Andi: Yogyakarta

Macey, W.H \& Schneider, B. (2008). The Meaning of Employee Engagement. Industrial and Organizational Psychology Vol. 1: hal. 3-30

Mathis, R.L. \& J.H. Jackson. 2006. Human Resource Management: Manajemen Sumber Daya Manusia. Terjemahan Dian Angelia. Jakarta: Salemba Empat.

May, D., dkk. 2004. The Psychological Conditions of Meaningfulness, Safety and Availability and The Engagement of The Human Spirit at Work. Journal of Occupational and Organizational Psychology. Vol. 77, h. 11-37

Mulki, J. P., Jaramillo, J. F., \& Locander, W. B. (2008). Effect of ethical climate on turnover intention: Linking attitudinal- and stress theory. Journal of Business Ethics, 78(4), 559-574.

https://www.researchgate.net/publication/342762371_Kepuasan_Kerja_Sebagai_ Variabel_Mediasi_Hubungan_Antara_Employee_Engagement_dan_Organizatio nal Commitment [accessed Jul 15 2020].

Ni Made Dwi Puspitawati dan I Gede Riana. 2014. Pengaruh Kepuasan Kerja terhadap Komitmen Organisasional dan Kualitas Layanan. Jurnal Manajemen Strategi Bisnis dan Kewirausahaan Vol.8 No.1, Februari 2014.

Robinson, D., Perryman, S \& Hayday, S. (2004). The Drivers of Employee Engagement. http://www.wellbeing4business.co.uk/docs/Article\%20\%20Engagement\%20research.pdf

Robbins, Stephen P \& Judge, Timothy A. 2013. Organizational Behavior Edition. 15. New Jersey: Pearson Education

Saks, A.M. (2006). Antecedents And Consequences Of Employee Engagement. Journal of Managerial Psychology Vol. 21 No. 7, 2006

Schaufeli, W.B., dan Bakker, A.B. 2004. Job Demands, Job Resources, And Their Relationship With Burnout And Engagement: A Multi-Sample Study. Journal of Organizational Behavior, 25, 293-315.

Schaufeli,W. B., Salanova, M., Gonzalez-Romá, V., \& Bakker, A. B. (2002). The Measurement Of Engagement And Burnout: A Confirmative Analytic Approach. Journal of Happiness Studies. Vol. 3, Issue 1: hal. 71-92

Schwepker, C.H, (2014), Impact of Satisfaction with Sales Supervisor on Offering Client Value and Customer Oriented Selling. Journal of Selling, Vol. 14, h. 43-54

Sopiah. 2008. Perilaku Organisasi, Yogyakarta: Andi

Susanti Saragih. 2013. Anteseden dan Konsekuensi Employee Engagement: Studi pada Industri Perbankan. Seminar Nasional dan Call for Paper, Universitas Kristen Maranatha, Bandung 19-20 Juni 2013; ISSN 978-979-19940-2-6. 